\title{
ALGORITMA NAÏVE BAYES UNTUK KLASIFIKASI SUMBER BELAJAR BERBASIS TEKS PADA MATA PELAJARAN PRODUKTIF DI SMK RUMPUN TEKNOLOGI INFORMASI DAN KOMUNIKASI
}

\author{
Admaja Dwi Herlambang ${ }^{1}$ Satrio Hadi Wijoyo ${ }^{2}$ \\ ${ }^{1,2}$ Pendidikan Teknologi Informasi, Fakultas Ilmu Komputer, Universitas Brawijaya \\ Email: ${ }^{1}$ herlambang@ub.ac.id, ${ }^{2}$ satriohadi@ub.ac.id
}

(Naskah masuk: 01 Desember 2018, diterima untuk diterbitkan: 02 Juli 2019)

\begin{abstract}
Abstrak
Salah satu komponen esensial dalam kegiatan pembelajaran di Sekolah Menengah Kejuruan Rumpun Teknologi Informasi dan Komunikasi (SMK TIK) adalah ketersediaan sumber belajar mata pelajaran produktif. Media internet atau online adalah sumber belajar yang berbentuk media elektronik yang dapat dimanfaatkan oleh siswa dan guru melalui jaringan internet. Salah satu bentuk media online adalah halaman web berformat html (Hypertext Markup Language) yang berupa dokumen teks sangatlah banyak. Sehingga sumber belajar tersebut perlu di kelompokkan berdasarkan kriteria atau ciri esensial setiap mata pelajaran produktif di SMK TIK. Proses pengelompokkan menggunakan algoritma Naive Bayes karena algoritma tersebut dapat digunakan untuk dokumen teks dan menggunakan teorema Bayes dengan menganggap semua atribut saling tidak berhubungan. Tujuan penelitian ini adalah untuk mendeskripsikan hasil klasifikasi dan evaluasi kualitas klasifikasi sumber belajar berbasis teks dengan menggunakan Algoritma Naïve Bayes. Tahapan penelitian yang dilakukan adalah pengoleksian data set, pemrosesan awal dengan text mining, pembobotan Tf-Idf, pengklasifikasian Naïve Bayes, dan evaluasi akurasi. Pengklasifikasian teks menghasilkan sembilan kelompok mata pelajaran produktif dan pengujian menghasilkan nilai akurasi tertinggi $81,48 \%$, sedangkan nilai akurasi terendah sebesar 79,63\%.
\end{abstract}

Kata kunci: sumber belajar, text mining, algoritma nä̈ve bayes, sekolah menengah kejuruan, teknologi informasi dan komunikasi

\section{NAÏVE BAYES ALGORITHM FOR TEXT BASED LEARNING RESOURCES CLASSIFICATION IN PRODUCTIVE SUBJECT AT INFORMATION AND COMMUNICATION TECHNOLOGY VOCATIONAL HIGH SCHOOL}

\begin{abstract}
The availability of learning resources for productive subjects is one of the essential components in learning activities for Vocational High Schools, especially for Information and Communication Technology competence field. Internet or online media is a learning resource in the form of electronic media that can be used by students and teachers through the internet. One form of online media is a web page formatted in .html (Hypertext Markup Language) in the form of very many text documents. So that learning resources need to be grouped based on the essential criteria or characteristics of each productive subject in Vocational High Schools. The grouping process uses the Naive Bayes algorithm because the algorithm can be used to text documents and use the Bayes theorem by assuming all attributes are mutually unrelated. The purpose of the study was to describe the results of the classification and classification quality evaluation of text-based learning sources using the Naïve Bayes Algorithm. The stages of the research carried out are collecting data sets, pre-processing with text mining, Tf-Idf weighting, Naïve Bayes classifying, and accuracy evaluation. Text classification results shows that there are nine productive subject groups and based on uji results shows that the highest accuracy value was 81,48\%, while the lowest accuracy value was 79,63\%.
\end{abstract}

Keywords: learning resource, text mining, nä̈ve bayes algorithm, vocational high school, information and communication technology

\section{PENDAHULUAN}

Kebutuhan calon pekerja bidang Teknologi Informasi dan Komunikasi (TIK) lulusan Sekolah
Menengah Kejuruan (SMK) semakin meningkat dengan bukti bahwa Direktorat Pembina SMK menambah satu rumpun keilmuan SMK TIK di 
tahun 2018, yaitu jurusan Sistem Informatika, Jaringan, dan Aplikasi (SIJA) (Kurikulum, 2017). Artinya, jurusan Sistem Informatika dapat melengkapi kebutuhan penyedia lapangan kerja bidang TIK untuk lulusan SMK yang semula hanya terbagi menjadi tiga jurusan, yaitu jurusan Rekayasa Perangkat Lunak (RPL), Teknik Komputer dan Jaringan (TKJ), dan Multimedia (MM).

Penciptaan calon pekerja bidang TIK yang memiliki relevansi dengan kebutuhan penyedia lapangan kerja harus didukung oleh institusi SMK dengan cara menyajikan kegiatan pembelajaran yang bermutu. Perkembangan teknologi informasi dan komunikasi (TIK) dewasa ini memunculkan sumber belajar yang mudah diakses sehingga dapat memperkaya interaksi antara guru dan siswa selama proses pembelajaran. Media internet atau online adalah sumber belajar yang berbentuk media elektronik yang dapat dimanfaatkan oleh siswa dan guru melalui jaringan internet. Salah satu bentuk dokumen yang menggunakan media online adalah halaman web berformat .html (Hypertext Markup Language). Media online memiliki beberapa keunggulan, yaitu, informasinya senantiasa up to date (senantiasa terbaru), informasinya bersifat real time, dan informasinya bersifat praktis.

Ketersedian sumber belajar berbentuk halaman web dan berformat .html sangat melimpah. Hal ini dapat dibuktikan melalui Google Search Engine dengan kata kunci "Sistem Operasi untuk SMK RPL" dan menghasilkan lebih dari 70.000 dokumen berformat .html. Apabila dokumen tersebut tidak diatur berdasarkan isi esensial setiap materi mata pelajaran, maka berpotensi akan menyulitkan guru dan siswa dalam kegiatan memilih materi pelajaran yang relevan dengan kebutuhan pembelajaran. Pengaturan dokumen teks dapat dilakukan dengan klasifikasi teks secara otomatis pada masing-masing dokumen tersebut berdasarkan kriteria atau ciri esensial setiap mata pelajaran produktif di SMK TIK.

Pengklasifikasian teks adalah sebuah area dimana algoritma klasifikasi digunakan pada dokumen-dokumen teks (Sriram et al., 2010). Pada saat ini terdapat bermacam-macam algoritma klasifikasi yang dapat digunakan untuk klasifikasi dokumen teks. Penggunaan algoritma ini menggunakan keseluruhan probabilitas, yaitu probabilitas dokumen terhadap kategori (prior). Kemudian teks akan terkategori berdasarkan probabilitas maksimumnya (posterior). Dengan kata lain, algoritma ini mengasumsikan bahwa ada atau tidaknnya atribut tertentu pada kelas yang tidak memiliki hubungan dengan ada tidaknya atribut yang lain (Yuan, 2010). Karena Algoritma Naive Bayes merupakan salah satu algoritma klasifikasi yang dapat digunakan untuk dokumen teks. Algoritma klasifikasi ini menggunakan teorema Bayes yang ada pada teori probabilitas dengan menganggap semua atribut saling tidak berhubungan.

Algoritma klasifikasi Naive Bayes untuk klasifikasi dokumen teks telah dilakukan oleh beberapa peneliti. Hamzah (2012) melakukan penelitian untuk melihat performa dari algoritma Naive Bayes dalam pengelompokan teks yang berbentuk teks berita dan akademis berupa abstrak dari berbagai disiplin ilmu. Terdapat 1000 dokumen teks berita dan 450 dokumen tesk abstrak akademik yang digunakan pada penelitian tersebut. Hasil penelitian tersebut memperlihatkan bahwa pada dokumen teks berita memiliki nilai akurasi maksimal sebesar 91\% sedangkan pada dokumen teks abstrak akademik sebesar $82 \%$. Penelitian oleh Chandra, Indrawan, \& Sukajaya (2016) menggunakan algoritma klasifikasi Naive Bayes untuk melakukan pengelompkkan dokumen teks berita politik, dokumen teks berita ekonomi, dokumen teks berita news, dokumen teks berita edukasi, dokumen teks berita kesehatan, dokumen teks berita travel, dan dokumen teks berita olahraga pada situs www.kompas.com. Hasil penelitian tersebut menunjukkan hasil akurasi sebesar 78.66\% untuk data uji berita ekonomi, news, edukasi, kesehatan, olahraga, entertainment, dan lain-lain dalam Bahasa Indonesia. Sehingga perlu ada penelitian terkait implementasi algoritma Naïve Bayes untuk mengklasifikasikan sumber belajar.

Sumber belajar merupakan segala sumber daya yang bisa digunakan oleh siswa untuk mendukung proses pembelajarannya (Hillier, 2005). Sumber belajar utama yang dapat digunakan adalah berupa sumber belajar elektronik yang didukung dengan teknologi jaringan komputer atau internet. Materi pembelajaran berkualitas yang tersedia di internet dapat dijadikan sebagai sumber belajar primer untuk siswa (Hillier, 2005). Siswa sangat diajurkan di dalam proses pembelajaran di SMK rumpun TIK untuk menggunakan internet. Siswa sangat terbantu dalam mendapatkan materi yang untuk pelajarinya, selain itu siswa juga dapat memperkaya referensi materi untuk menyelesaikan masalah (Malmi \& Korhonen, 2008).

Sumber belajar di ineternet banyak disajikan dalam bentuk teks, sehingga metode text mining sangatlah tepat dalam pencarian pola dokumen teks dalam proses pengklasifikasian. Text mining yaitu suatu proses penggalian data teks yang dilakukan secara komputer untuk memperoleh suatu informasi yang baru dari data teks. Suatu informasi yang tidak diketahui sebelumnya dan mendapatkan suatu informasi yang implisit. Informasi implisit tersebut dilakukan ekstraksi secara otomatis dari sumbersumber data teks yang berbeda-beda (Fieldman et al., 2006). Sehingga tujuan penelitian ini adalah untuk mendeskripsikan hasil klasifikasi dan evaluasi kualitas klasifikasi sumber belajar berbasis teks dengan menggunakan Algoritma Naïve Bayes. 
Langkah awal pada text mining adalah melakukan perubahan data yang tidak tersusun secara sistematis menjadi data yang tersusun (Torunoğlu et al., 2011). Proses yang dilakukan pada tahap ini seperti casefolding, cleaning item (pembersihan kata), tokenizing, filtering (stopword removal), dan stemming (Agusta, Kristen, \& Wacana, 2009; Nurjanah, Hamdani, \& Astuti, 2013).

\section{METODOLOGI}

Tahapan penelitian yang telah dilakukan terdiri dari kegiatan pengoleksian dataset, pemrosesan awal dengan text mining, pembobotan Tf-Idf, pengklasifikasian Naïve Bayes, dan evaluasi akurasi. Tahapan penelitian ditunjukkan pada Gambar 1.

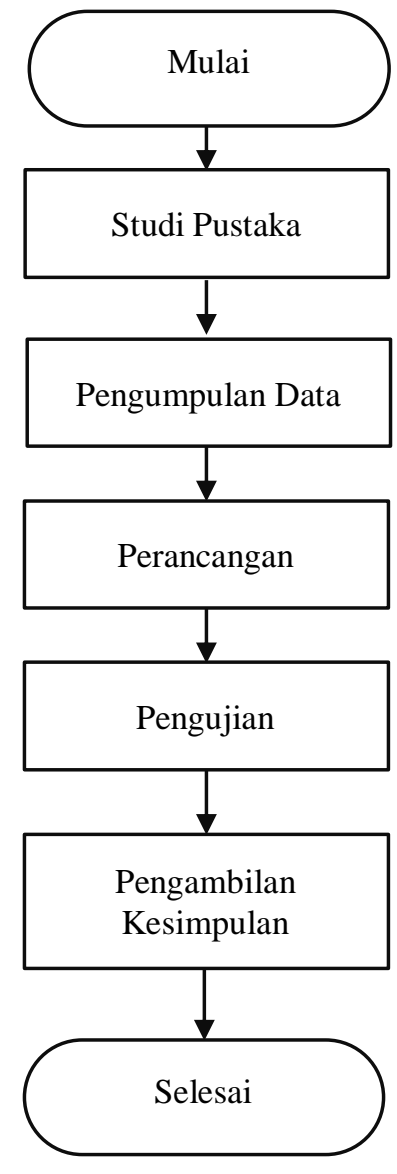

Gambar 1. Metodologi Penelitian

Pada tahap pengoleksian dataset, peneliti melakukan pengumpulan data berupa dokumen teks sumber belajar. Data yang digunakan pada penelitian ini adalah dokumen teks atau artikel teks yang diperoleh dari website yang berisikan materi-materi mata pelajaran produktif dari SMK Rumpun Teknologi Informasi dan Komunikasi. Dokumen teks yang diambil hanya materi yang terbagi pada RPL, TKJ, MM, dan SIJA. Data diambil dengan cara manual selama 2 bulan dari beberapa situs internet, yaitu antara bulan Maret sampai April tahun 2018. Data dikelompokkan menjadi sembilan kelas yang ditunjukkan pada Tabel 1 .

Tabel 1. Variabel Pada Setiap Kelas

\begin{tabular}{lc}
\hline \multicolumn{1}{c}{ Mata Pelajaran/Nama Kelas } & Variabel Kelas \\
\hline Animasi 2D & $K_{1}$ \\
Animasi 3D & $K_{2}$ \\
Desain Multimedia & $K_{3}$ \\
Basis Data & $K_{4}$ \\
Pemodelan Perangkat Lunak & $K_{5}$ \\
Pemrograman Dasar & $K_{6}$ \\
Komputer Terapan Jaringan & $K_{7}$ \\
Komunikasi Data & $K_{8}$ \\
Sistem Operasi & $K_{9}$ \\
\hline
\end{tabular}

Kemudian dilakukan tahap perancangan sistem yang terdiri tiga bagian, yaitu tahap preproses, tahap pembobotan kata (tf-idf), dan klasifikasi dokumen menggunakan Algoritma Naïve Bayes. Tahap praproses dalam penelitian ini terdiri empat bagian, yaitu pemenggalan kata (tokening item), pembersihan kata (cleaning item), penghapusan stopword stopword removal), dan stemming (kata dasar). Setelah dapat kata-kata dalam dokumen teks, selanjutnya menghitung bobot kemunculan kata dengan teknik Item Frequency Inverse Document Frequency atau bisa disebut juga dengan Tf-Idf. TfIdf merupakan konsep pembobotan item dari dokumen teks. Pembototan Tf-Idf dapat digunakan pada sebuah kalimat dari dokumen teks. Selanjutnya data bobot Tf-Idf diklasifikasikan menggunakan Algoritma Naïve Bayes. Pada tahap pengujian peneliti melakukan pengujian dengan menghitung akurasi dari evaluasi Algoritma Naïve Bayes. Dataset yang nanti didapatkan akan dijadikan data latih dan data uji. Standar yang digunakan dalam melakukan evaluasi yaitu dengan mengukur kinerja sistem yaitu akurasi. Seberapa dekat jarak suatu hasil pengukuran terhadap angka sebenarnya disebut nilai akurasi. Dalam penelitian ini pengujian akurasi dilakukan untuk mengetahui performa dari sistem dalam memberikan kesimpulan prediksi. Perhitungan nilai akurasi dilakukan dengan menggunakan Persamaan (1).

$$
\text { Nilai Akurasi }=\frac{\text { jumlah data akurat }}{\text { jumlah seluruh data }} \times 100 \%
$$

\section{HASIL}

Analisis kebutuhan sistem pada penelitian ini dilakukan untuk mengidentifikasi permasalah yang terjadi di 2 SMK TIK di Kota Malang untuk selanjutnya dapat menghasilkan perancangan sistem yang sesuai dengan kebutuhan SMK TIK. Sistem disini diposisikan sebagai test-bed implementasi Algoritma Naïve Bayes. Setelah melakukan wawancara dengan pihak sebanyak 2 SMK TIK yang ada di Kota Malang (SMKN 12 Malang dan SMK Widyagama Malang), bahwa siswa masih merasa kebingungan dan kesulitan saat mencari materi sekolah di website. Siswa juga tidak tahu 
materi tersebut masuk dalam bidang keminatan yang mana dalam SMK TIK. SMK TIK memiliki beberapa mata pelajaran yang terbagi dalam tiga keminatan, yaitu RPL, TKJ, MM, dan SIJA.

Terdapat lima (5) Use Case yang menggambarkan fungsi sistem dalam penelitian ini, yaitu Menghitung proses klasifikasi Naïve Bayes; Import Data; Export Data; Melihat Data Latih, dan Melihat Data Uji. Actor pada aplikasi terdapat dua orang yaitu siswa atau guru. Lima (5) fungsi yang didefinisikan tersebut merupakan jawaban dari kebutuhan yang muncul dari hasil identifikasi masalah. Gambar 2 mendefinisikan Use Case yang terdapat pada sistem.

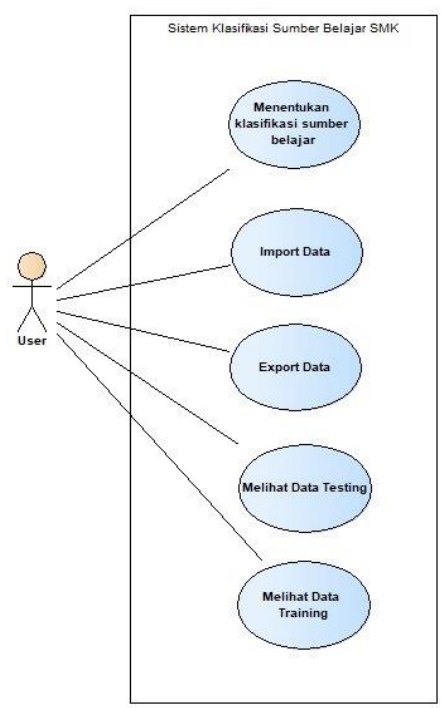

Gambar 2. Use Case Sistem Klasifikasi Sumber Belajar SMK

Dataset yang berhasil diperoleh selama 2 bulan adalah sebanyak 235 data dalam bentuk file notepad (txt). Dataset dibagi sesuai kelasnya masing-masing, yaitu $K_{1}$ sebanyak 32 data, $K_{2}$ sebanyak 32 data, $K_{3}$ sebanyak 32 data, $K_{4}$ sebanyak 21 data, $K_{5}$ sebanyak 21 data, $K_{6}$ sebanyak 21 data, $K_{7}$ sebanyak 32 data, $K_{8}$ sebanyak 22 data, dan $K_{9}$ sebanyak 22 data. Dataset dijadikan sebagai data latih dan data uji untuk Algoritma Naïve Bayes. Data latih dan data uji ini adalah data yang berbedabeda.

Pengujian dilakukan sebanyak 4 kali dengan perbandingan data latih dan data uji yang sama. Data uji pertama menggunakan 20 data dengan jumlah tiap kelas. Data uji pertama menggunakan 36 data dari jumlah semua kelas. Data uji kedua menggunakan 54 data dari jumlah semua kelas. Data uji ketiga menggunakan 72 data dari jumlah semua kelas. Data uji keempat menggunakan 120 data dari jumlah semua kelas. Data latih yang digunakan berjumlah 55 data. Jumlah data latih dibuat tetap jumlahnya dalam setiap percobaan karena untuk menguji apakah jika menggunakan data uji yang berbeda akan mempengaruhi hasil akurasi prediksi sistem. Gambar 3 menunjukkan bahwa dataset dapat ditampilkan pada sistem.

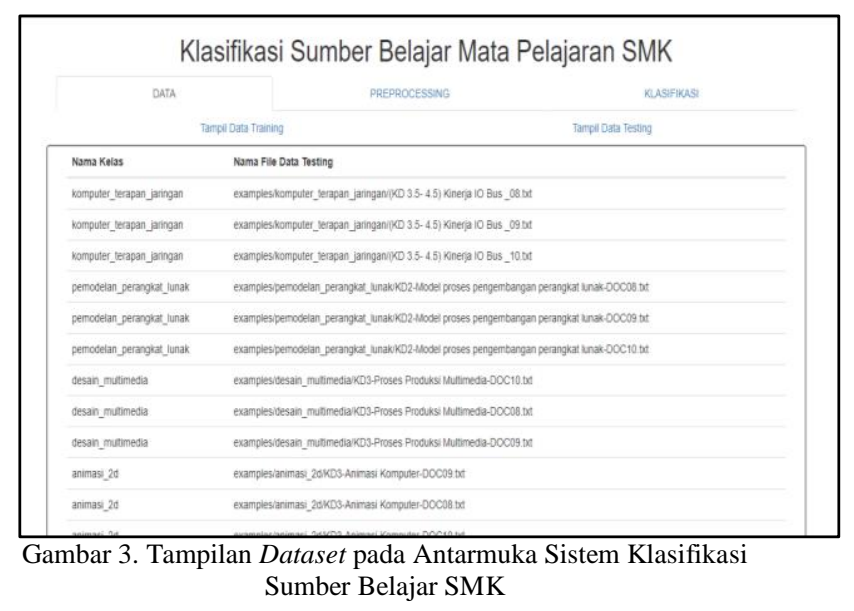

Semua data latih menggunakan data sebanyak 55 data. Percobaan ke-1 menggunakan data uji sebanyak 36 data. Dari hasil percobaan ke-1 diperoleh nilai akurasi sebesar 80,56\%. Sebanyak 29 data yang tepat atau sesuai dengan data target. Sedangkan 7 data dari sistem tidak sesuai dengan data target. Percobaan ke-2 menggunakan data uji sebanyak 54 data. Dari hasil percobaan ke-2 diperoleh nilai akurasi sebesar 79,63\%. Sebanyak 43 data yang tepat atau sesuai dengan data target. Sedangkan 11 data dari sistem tidak sesuai dengan data target. Percobaan ke-3 menggunakan data uji sebanyak 72 data. Dari hasil percobaan ke-3 diperoleh nilai akurasi sebesar $80,56 \%$. Sebanyak 58 data yang tepat atau sesuai dengan data target. Sedangkan 14 data dari sistem tidak sesuai dengan data target. Percobaan ke-4 menggunakan data uji sebanyak 120 data. Dari hasil percobaan ke-4 diperoleh nilai akurasi sebesar 81,48\%. Sebanyak 98 data yang tepat atau sesuai dengan data target. Sedangkan 22 data dari sistem tidak tepat dengan data kelas aslinya. Hasil pengujian penelitian ini diperoleh nilai akurasi terbesar dari semua percobaan adalah $81,48 \%$, sedangkan nilai akurasi terkecil dari semua percobaan adalah $79,63 \%$. Perbandingan nilai akurasi untuk setiap percobaan disajikan pada Tabel 2 .

Tabel 2. Hasil Perbandingan Akurasi Pengujian

\begin{tabular}{ccccc}
\hline $\begin{array}{c}\text { Pengujian } \\
\text { Ke- }\end{array}$ & $\begin{array}{c}\text { Jumlah } \\
\text { Data Uji }\end{array}$ & $\begin{array}{c}\text { Jumlah } \\
\text { Data } \\
\text { Yang } \\
\text { Tepat }\end{array}$ & $\begin{array}{c}\text { Jumlah } \\
\text { Data } \\
\text { Yang } \\
\text { Salah }\end{array}$ & Akurasi \\
\hline 1 & 36 Data & 29 Data & 7 Data & $80,56 \%$. \\
2 & 54 Data & 43 Data & 11 Data & $79,63 \%$ \\
3 & 72 Data & 58 Data & 14 Data & $80,56 \%$ \\
4 & 120 Data & 98 Data & 22 Data & $81.48 \%$ \\
\hline
\end{tabular}

\section{SIMPULAN}

Kelompok data sumber belajar yang diperoleh sebanyak 235 data yang sudah terklasifikasi berdasarkan masing-masing kelas. Data akan dikelompokkan menjadi 9 kelas yaitu Animasi 2D, Animasi 3D, Desain Multimedia, Basis Data, Pemodelan Perangkat Lunak, Pemrograman Dasar, 
Komputer Terapan Jaringan, Komunikasi Data, dan Sistem Operasi. Data uji pertama menggunakan 36 data dengan jumlah tiap kelas. Data uji kedua menggunakan 54 data dengan jumlah tiap kelas. Data uji ketiga menggunakan 72 data dengan jumlah tiap kelas. Data uji keempat menggunakan 120 data dengan jumlah tiap kelas berbeda. Data latih yang digunakan berjumlah 55 data. Pengujian pada data sumber belajar menggunakan algoritma Naive Bayes menghasilkan nilai akurasi tertinggi 81,48, sedangkan nilai akurasi terendah sebesar 79,63\%.

$$
\text { Penelitian }
$$$$
\text { selanjutnya }
$$

perlu mempertimbangkan pemilihan data latih, karena pola dari atribut data latih dijadikan sebagai aturan dalam penentuan kelas pada data uji sehingga nilai akurasi pengujian juga berbeda. Penelitian selanjutnya juga perlu mempertimbangkan kompleksitas/ketelitian pada tahap pre-processing, karena kualitas data yang dihasilkan dari tahap preprocessing juga bisa menentukan nilai akurasi.

\section{DAFTAR PUSTAKA}

AGUSTA, L., KRISTEN, U., \& WACANA, S. 2009. Perbandingan Algoritma Stemming Porter Dengan Algoritma Nazief \& Adriani Untuk Stemming Dokumen Teks Bahasa Indonesia. Konferensi Nasional Sistem dan Informatika 2009, (KNS\&I09-036), pp.196-201.

ALLAN, J., KUMARAN, G., \& STORAGE, H.I. 2003. Stemming in the Language Modeling Framework. (June), pp.455-456.

CHANDRA, D. N., INDRAWAN, G., \& SUKAJAYA, I.N. 2016. Klasifikasi Berita Lokal Radar Malang menggunakan Metode Naive Bayes dengan Atribut N-Gram. Jurnal Ilmiah Teknologi dan Informasi ASIA (JITIKA). 10(1): hlm. 11-19.

FELDMAN, R., \& JAMES, S. 2006. The Text mining Handbook: Advanced Approaches in Analyzing Unstructured Data. Cambridge: Cambridge University Press.

HAMZAH, A. 2012. Klasifikasi Teks dengan Naive Bayes Classifier (NBC) untuk Pengelompokkan Teks Berita dan Abstract Akademis. Prosiding Seminar Nasional Aplikasi Sains \& Teknologi (SNAST) Periode III. ISSN : 1979-9111, Vol. 3.

HILLIER, Y. 2005. Reflective Teaching in Further and Adult Education: Second Edition. London: Continuum.

KURIKULUM. 2017. Kompetensi Inti dan Kompetensi Dasar (KI \& KD) SMK/MAK, (Online), (http://psmk.kemdikbud.go.id/kikd2017), diakses 1 Februari 2017.

MALMI, L. \& KORHONEN, A. 2008. Active Learning and Examination Methods in a Data Structures and Algorithms Course. Dalam Caspersen, E. M. \& Kolling, M.
(Eds.). Reflections on the Teaching of Programming: Methods and Implementions (hlm. 210-227). Berlin: Springer.

NURJANAH, M., HAMDANI, \& ASTUTI, I. F. 2013. Penerapan Algoritma Item Frequency-Inverse Document Frequency (TF-IDF) untuk Text mining. Jurnal Informatika Mulawarman. 8 (3): hlm. 110113.

TORUNOĞLU, D., ÇAKIRMAN, E., GANIZ, M.C., AKYOKUŞ, S., \& GÜRBÜZ, M.Z. 2011. Analysis Of Preprocessing Methods On Classification of Turkish Texts. INISTA 2011 - 2011 International Symposium on INnovations in Intelligent SysTems and Applications, pp.112-117.

YUAN, L. 2010. An Improved Naive Bayes Text Classification Algorithm In Chinese Information Processing. Proceedings of the Third International Symposium on Computer Science and Computational Technology (ISCSCT '10), Jiaozuo, P. R. China, 14-15, August 2010, pp. 267-269. 
Halaman ini sengaja dikosongkan 